\title{
THE CONTENT OF IRON AND MANGANESE IN POTATO TUBERS TREATED WITH BIOSTIMULATORS AND THEIR NUTRITIONAL VALUE
}

\author{
MYSTKOWSKA, I. \\ State School of Higher Education, Biała Podlaska \\ Sidorska 95/97, 21-500 Biała Podlaska, Poland \\ (e-mail:imystkowska@op.pl)
}

(Received $30^{\text {th }}$ Jun 2018; accepted $6^{\text {th }}$ Sep 2018)

\begin{abstract}
The aim of the study was to evaluate the content and nutritional value of iron and manganese in edible potato tubers. Field experiments were carried out in 2015-2017 with the use of biostimulators on the individual farm in Międzyrzec Podlaski, Poland. The experiment was based on the random splitplot method. The influence of two factors was examined. The first row factor included three varieties of edible potato: Honorata, Jelly, Tajfun, and the second row - five methods of using biostimulators: Kelpak SL, Titanit, GreenOk, BrunatneBio Złoto Cytokininy, potato plants sprayed with distilled water were the control object. Potato plants were treated three times with biostimulators (at the beginning of flowering, at full flowering and after plant flowering). The high amount of rainfall in 2017 contributed to the increase of iron and manganese content in potato tubers. Plant tubers treated with the BrunatneBio Złoto Cytokiny preparation were characterized by the highest content of iron and manganese in comparison to plants from the control object. Titanite reduced the content of manganese and iron in tubers. The content of micronutrients in tubers was significantly differentiated by the genotype of the variety. The highest Mn concentration was found in the Jelly tubers, $\mathrm{Fe}$ in the Honorata variety. The average content of manganese was $4.4 \mathrm{mg} \cdot \mathrm{kg}^{-1}$, and iron $43.5 \mathrm{mg} \cdot \mathrm{kg}^{-1}$, which covers the demands in 1.7 and $5.5 \%$ per day, respectively.
\end{abstract}

Keywords: edible potato, minerals, nutritional value, bioregulators

\section{Introduction}

Nutritionists encourage an increase in the consumption of potato (Solanum tuberosum L.) tubers due to low caloric value and high nutritional and dietary values. The calories cooked potato (50-90 kcal per $100 \mathrm{~g}$ ) slightly exceeds the energy value of apples (54 kcal per $100 \mathrm{~g}$ ) or milk (62 kcal per $100 \mathrm{~g}$ ), it is also three times smaller than wheat bread's (275 kcal per $100 \mathrm{~g}$ ) and seven times smaller than chcolate's (540 kcal per $100 \mathrm{~g}$ ) (Kunachowicz et al., 2010). This plant also provides a number of valuable nutrients, such as: carbohydrates, proteins, vitamins $\left(\mathrm{C}, \mathrm{B}_{1}, \mathrm{~B}_{2}, \mathrm{PP}, \mathrm{B}_{6}\right)$, minerals (K, Mg, Fe, Cu, Mn, J), dietary fibre (Lutaladio and Castaidi, 2009).

The nutritional value of potato tubers, in addition to protein, carbohydrates and vitamins, is also determined by the content of minerals that after digestion and absorption into the blood are used by the body as a building block or a factor regulating life processes (Żechałko-Czajkowska, 1992; Spiak, 2000; LAW ON food and Nutrition Safety, 2009). Potato tubers contain 1-1.2\% of minerals. Minerals are those components which remain in the form of ash after burning. In order for the human body to function properly, it must receive all necessary nutrients from outside, including minerals. Microelements control enzymatic processes, the largest amount (73-79\%) comes from manure (Kaniuczak et al., 2009). In modern agriculture, more and more attention is paid not only to the amount of harvested crop, but also to its quality. According to Czuba (2000), the content of micronutrients in the crop yields is 
an important agrotechnical issue, as well as an important quality feature assessed according to consumption and feed criteria. For this purpose, in addition to pesticides, a number of preparations are used as plant development regulators or biostimulators (Maciejewski et al., 2007). Biostimulators control mineral metabolism, increase the plant's resistance to stressful environmental conditions (Sawicka and Mikos-Bielak, 2002; Wierzbowska et al., 2015; Papenfus et al., 2013; Panda el al., 2012), as well as increase resistance to attacks of diseases and pests (Grzyś, 2012). Several authors have demonstrated the effect of acid $\mathrm{pH}<5.5$ on increasing the availability of manganese and iron in it (Prośba-Białczyk and Mydlarski, 2000; Rogóż, 2009). Iron participates in the process of photosynthesis and nucleic acid metabolism, stimulates the formation of chlorophyll, participates in the reduction of nitrates and the binding of free nitrogen, and regulates oxidation-reduction reactions. Manganese is involved in oxidation-reduction processes, photosynthesis, decarboxylation and binding of free nitrogen (Kabata-Pendias and Pendias, 1993; Zarzecka, 2004). The aim of the article is to examine the effect of biostimulators on the content of manganese and iron in potato tubers and to assess the nutritional value of the selected minerals.

\section{Materials and methods}

\section{The experimental site}

Potato tubers from a field experiment carried out in 2015-2017 in an individual farm in Międzyrzec Podlaski, Poland were the material for testing. The experiment was established in triplicate using the random split-plot method, on the soil included in the very good rye complex, class IVA. In individual years of research, soils differed in the content of organic matter and absorbable macro-elements. In 2015 and 2016, the soil was characterized by slightly acidic reaction, and in the last year of research, alkaline. The content of organic matter ranged from 15.0 to $18.7 \mathrm{~g} / \mathrm{kg}$. The content of absorbable phosphorus $(\mathrm{P})$ was from high to very high, potassium (K) from medium to very high, and magnesium $(\mathrm{Mg})$ was high. The first factor was three moderately early varieties of edible potato: Honorata, Jelly and Tajfun, and the second one, four types of biostimulators used in three dates (beginning of flowering, fully flowering and after flowering of plants):

1. Control object - without the use of biostimulators spraying with distilled water

2. Biostimulator Kelpak ${ }^{\circledR}$ SL (active substance - Ecklonia maxima algae extract) containing plant hormones: auxin $-11 \mathrm{mg} / 1$ and cytokinin $-0.031 \mathrm{mg} \cdot 1$, at a dose of $0.20 \mathrm{~L} \cdot \mathrm{ha}^{-1}$

3. Biostimulator Tytanit ${ }^{\circledR}$ (active substance - titanium) at a dose of $0.20 \mathrm{~L} \cdot \mathrm{ha}^{-1}$,

4. Biostimulator GreenOk ${ }^{\circledR}$ (active substance - humus substances $20 \mathrm{~g} / \mathrm{l}$ ) at a dose of $0.20 \mathrm{~L} \cdot \mathrm{ha}^{-1}$

5. Biostimulator BrunatneBio Złoto (active substances - plant hormones: auxin $-0.06 \mathrm{mg} \cdot 1$ and cytokinin $-12 \mathrm{mg} \cdot 1$, ) at a dose of $0.20 \mathrm{~L} \cdot \mathrm{ha}^{-1}$

The forecrop for potato in particular years of research was winter wheat. After harvesting the forecrop, a team of post-harvest crops was made. In autumn, each year preceding planting, natural fertilization in the form of manure in the amount of $25.0 \mathrm{t} \cdot \mathrm{ha}^{-1}$ and mineral fertilization with phosphorus-potassium in the amount of $\mathrm{P}-$ $44.0\left(100 \mathrm{P}_{2} \mathrm{O}_{5} \cdot 0.44\right) \mathrm{kg} / \mathrm{ha}$ (lubofos for potatoes $7 \%$ ) and $\mathrm{K}-124.5\left(150 \mathrm{~K}_{2} \mathrm{O} \cdot 0.83\right)$ 
$\mathrm{kg} \cdot \mathrm{ha}^{-1}$ (lubofos for potatoes $25 \%$ ) was applied. These fertilizers were plowed preseason plowing. Nitrogen fertilizers were sown in the spring in an amount of $\mathrm{N} 100 \mathrm{~kg} / \mathrm{ha}$ (nitro-chalk 27\%) and mixed with the soil using a cultivator. Potatoes were planted manually under the marker at a spacing of $67.5 \times 37 \mathrm{~cm}$, in the third decade of April (2015, 2016, 2017). Each plot consisted of five ridges. Cultivation and care treatments were carried out in accordance with the requirements of correct agrotechnics and methodological assumptions of the experiment. Prior to harvest, random samples of tubers were collected from each plot and used for chemical analysis and assessment of consumption-related characteristics of the tubers.

\section{Chemical analysis methods}

Weight of about $0.2-0.3 \mathrm{~g}$ of sample was transferred to the PTFE vessel and $\mathrm{HNO}_{3}$ and HCL was added, 3:1 respectively. The vessels were placed in the rotor and loaded to the microwave. The following digestion program has been used:

Step $1-10^{\prime}$ at $350 \mathrm{~W}$

Step $2-35^{\prime}$ at $650 \mathrm{~W}$

Step 3 - cooling and ventilation

Mineralized samples were transferred to the $50 \mathrm{ml}$ flasks through filtering paper and diluted with ultra-pure water.

Samples were examined with SpectroBlue ICP OES spectrometer at the Regional Research Center for Environment, Agricultural and Innovative Technologies, Pope John II State School of Higher Education in Biała Podlaska. Analytical curves were built by diluting Bernd Kraft Der Standard Spectro Genesis ICAL Solutions and VHG SM68-1-500 Element Multi Standard 1 in 5\% $\mathrm{HNO}_{3}$. Operating parameters for ICP OES instrument: coolant flow: $12 \mathrm{1} / \mathrm{min}$; auxiliary flow: $0.901 / \mathrm{min}$; nebulizer flow: 0.78 1/min; pump speed: $30 \mathrm{Rpm}$; number of measurements: 3.

\section{Meteorological conditions}

The weather conditions in the potato growing years were shown by precipitation sums and average air temperatures in Table 1.

Table 1. Weather conditions during of potato vegetation

\begin{tabular}{|c|c|c|c|c|c|c|c|}
\hline \multirow{2}{*}{ Years } & \multicolumn{6}{|c|}{ Months } & \multirow{2}{*}{$\begin{array}{c}\text { April- } \\
\text { September }\end{array}$} \\
\hline & April & May & June & July & August & September & \\
\hline \multicolumn{8}{|c|}{ Air temperature $\left({ }^{\circ} \mathrm{C}\right)$} \\
\hline 2015 & 8.2 & 12.3 & 16.5 & 18.7 & 21.0 & 14.5 & 15.2 \\
\hline 2016 & 9.1 & 15.1 & 18.4 & 19.1 & 18.0 & 14.9 & 15.8 \\
\hline 2017 & 6.9 & 13.9 & 17.8 & 16.9 & 18.4 & 13.9 & 14.6 \\
\hline Multiyear mean 1996-2010 & 8.0 & 13.5 & 17.0 & 19.7 & 18.5 & 13.5 & 15.0 \\
\hline \multicolumn{8}{|c|}{ Rainfall (mm) } \\
\hline 2015 & 30.0 & 100.2 & 43.3 & 62.6 & 11.9 & 47.1 & 295.1 \\
\hline 2016 & 28.7 & 54.8 & 36.9 & 35.2 & 31.7 & 13.6 & 200.9 \\
\hline 2017 & 59.6 & 49.5 & 57.9 & 23.6 & 54.7 & 80.1 & 325.4 \\
\hline Multiyear sum (1996-2010) & 33.6 & 58.3 & 59.6 & 57.5 & 59.9 & 42.3 & 335.4 \\
\hline
\end{tabular}


The growing season of 2015 proved to be an average air temperature of $15.2{ }^{\circ} \mathrm{C}$, $0.2{ }^{\circ} \mathrm{C}$ higher than the long-term average and precipitation at $295.1 \mathrm{~mm}$. The highest average air temperature was recorded in 2016 and amounted to $15.8{ }^{\circ} \mathrm{C}$, it was higher than the long-term average by $0.8^{\circ} \mathrm{C}$, while this year was characterized by the lowest amount of precipitation $-200.9 \mathrm{~mm}$, lower by $134.5 \mathrm{~mm}$ from the long-term sum. The highest number of rainfall was recorded in the growing season of $2017-325.4 \mathrm{~mm}$ and the lowest average air temperature $-14.6{ }^{\circ} \mathrm{C}$ (Table 1).

\section{Statistical analysis}

Results of the study were analysed by ANOVA. Significance of sources of variation was checked with the Fisher-Snedecor test and the significance of differences between means was tested using the multiple comparison Tukey's test at the significance level of $P=0.05$. Statistical calculations were performed in Excel using the authors' own algorithm based on the split-plot mathematical model.

\section{Results and discussion}

The average iron content in tubers was $43.5 \mathrm{mg} \cdot \mathrm{kg}^{-1} \mathrm{~d} . \mathrm{m}$. , ranging from 41.5 to $46.4 \mathrm{mg} \cdot \mathrm{kg}^{-1}$ (Table 2). The research shows that the genetic factor had a significant effect on the iron content in potato tubers. The variety that contained the most of this ingredient was the Honorata variety, followed by Tajfun and Jelly. The influence of varietal properties on iron content is emphasized by Leszczyński and Lisińska (1986), Mikos-Bielak and Sawicka (1992), Gąsior (1996), as well as Sawicka (1996). Among the biostimulators used in the experiment, only the BrunatneBio Złoto biostimulator significantly increased the iron content in the tubers of the tested varieties. The factor that also significantly modified the content of the analysed component were the hydrothermal conditions prevailing during the years of research. High content of iron was found in tubers harvested in 2017 in which the sum of rainfall was 124 and $30 \mathrm{~mm}$ than in 2016 and 2015, respectively (Table 1). The problems of biostimulators on mineral content in potato tubers were investigated by Wierzbowska et al. (2015). When analysing the effect of Asahi SL, Bio-Algeen S90 and Kelpak SL biostimulators, the authors showed that the iron content in tubers was significantly modified only by the Kelpak SL biostimulator. The opposite direction of changes in iron content was observed by the authors in relation to the Bio-Algeen S90 biostimulator. In the light of the presented research, it should be stated that the iron content in tubers depends on the type of biostimulator and the mechanism of its impact on plants and on hydrothermal conditions. The large amount of rainfall caused that the potato tubers accumulated twice as much iron as in the remaining years. Lombardo et al. (2014) and Griffiths et al. (2012) found that the "mineral profile" can be influenced by the cultivation system. Lipiński et al. (2006) in their research proved that higher soil $\mathrm{pH}$ and higher humus content causes iron reduction. Iron affects the proper functioning of the circulatory system, participates in the synthesis of haemoglobin and in the oxidation and delivery of oxygen to tissues (Błoniarz et al., 2005). It is part of cytochrome oxidase, peroxidase and catalase enzymes (Jędrzejczak, 2004). The iron content in potato tubers treated with biostimulators was on average $43.5 \mathrm{mg} \cdot \mathrm{kg}^{-1} \mathrm{~d} . \mathrm{m}$., and the daily norm of this element is $8 \mathrm{mg}$ according to the recommendations of the Academy of Food Science and Nutrition in the USA (Wierzbicka, 2012). Consumption of 100 grams of potatoes covers the daily demand 
for iron in approx. 5.5\% of the daily requirement (Table 3). The established iron content in potato tubers corresponds to the research of: Prośba-Białczyk and Mydlarski (2000), Rogóż and Trąbczyńska (2009), Sawicka and Mikos-Bielak (2008), Różyło and Pałys (2006), Wierzbicka (2012), Wierzbicka and Trawczyński (2011) and Wierzbowska et al. (2015), who fund iron content in potato tubers from $26.9 \mathrm{mg} \cdot \mathrm{kg}^{-1}$ - $91.85 \mathrm{mg} \cdot \mathrm{kg}^{-1}$ d.m., while Kabata-Pendias and Pendias (1993) considered $21-58 \mathrm{mg} \cdot \mathrm{kg}^{-1}$ of dry matter as the optimal content, while Ostrowska et al. (1991) estimate that the content of this element in potato is $93-188 \mathrm{mg} \cdot \mathrm{kg}^{-1}$ of dry matter. The correct ratio of iron to manganese in feeds is assumed to be 2.5:1 (Rogóż, 2009). If it is larger, manganese deficiency is likely (Wierzbicka, 2012; Wierzbowska et al., 2015). In the tests carried out, the ratio was 10:1, which indicates a deficiency of manganese. The content of manganese in tubers treated with biostimulators was on average $4.4 \mathrm{mg} \cdot \mathrm{kg}^{-1} \mathrm{~d} . \mathrm{m}$., which with demand of 1.8-2.3 (Wierzbicka, 2012) per $100 \mathrm{~g}$ of tubers realizes the demand for this component in the range of about $1.7 \%$ (Table 3 ). The studies carried out show that varietal features were the dominant factor that influenced the formation of manganese content in potato tubers (Table 4). The variety that contained the most of this ingredient was the Jelly variety. The observed interaction between the varieties and the years proves the individual reaction of the varieties to the weather conditions in the research years. The highest average manganese content was obtained in the Jelly and Tajfun varieties in 2017 (with the highest rainfall total). Tubers originating from objects treated with biostimulators in relation to the control object were characterized by a significantly higher content of manganese. The content of manganese in tubers was significantly modified by the BrunatneBio Złoto biostimulator. The applied biostimulator reacted to the atmospheric conditions in the years of research as indicated by the object $\mathrm{x}$ years interaction. The BrunatneBio Złoto biostimulator caused a significant increase in manganese content in 2017, which turned out to be wet and cold. The level of manganese content in potato tubers in the conducted experiment coincides with that given by other authors - 3.6$15 \mathrm{mg} \cdot \mathrm{kg}^{-1}$ of dry mass (Kabata-Pendias and Pendias 1993; Sawicka, 1996; Sykut et al., 1998). In the studies by Mikos-Bielak (1999), the upper limit of the range was exceeded twice, and in Kucharzewski et al. (2002) almost ten times. The Mn concentration of approx. $500 \mathrm{mg} \cdot \mathrm{kg}^{-1}$ of dry mass is toxic for most plants (Kucharzewski and Dębowski, 2001). It should be emphasized that $\mathrm{Fe}$ and $\mathrm{Mn}$ accumulate mainly in the outer layer of the potato tuber, so their excess can be removed by peeling (Mikos-Bielak, 1999). In the research conducted by Wierzbicka and Trawczyński (2011), the average contents of micro-elemenys in the tubers of organic potatoes were equal to: Fe-46.9; $\mathrm{Mn}-7.3 \mathrm{mg} \cdot \mathrm{kg}^{-1} \mathrm{~d} . \mathrm{m}$. The spatial distribution of minerals in potato tubers is not even (Subramanian et al., 2011; Petryk and Bedla, 2010; Srek et al., 2012). According to Zarzecka (2004), some herbicides cause an increase in manganese in potato tubers. Kaniuczak et al. (2009) found in their research that liming reduces the content of manganese, and mineral fertilization increases the content of Mn in potato tubers. Manganese performs important functions in the plant. It takes part in the process of photosynthesis, the transformation of nitrogen compounds in the plant and in the biosynthesis of vitamin C (Jędrzejczak, 2004). It influences the uptake of phosphorus and iron from the soil. Manganese deficiency in potato delays plant development. In humans, it is responsible for the absorption of vitamins, the formation of connective tissue and bones, metabolism of carbohydrates, lipids and normal brain function (Wierzbicka, 2012). 
Table 2. Content of iron in tubers of potatoes depending on the biostimulator used

\begin{tabular}{c|c|c|c|c|c|c|c}
\hline \multirow{2}{*}{ Objects } & \multicolumn{3}{|c|}{ Cultivars } & \multicolumn{3}{c|}{ Years } & \multirow{2}{*}{ Mean } \\
\cline { 2 - 7 } & Honorata & Jelly & Tajfun & $\mathbf{2 0 1 5}$ & $\mathbf{2 0 1 6}$ & $\mathbf{2 0 1 7}$ & \\
\hline 1. Control object & 44.6 & 42.9 & 44.1 & 42.5 & 43.5 & 45.6 & 43.9 \\
2. Kelpak SL & 43.2 & 42.0 & 43.5 & 41.9 & 43.5 & 43.5 & 43.0 \\
3. Tytanit & 42.8 & 42.1 & 43.1 & 41.5 & 43.1 & 43.1 & 42.6 \\
4. GreenOk & 44.8 & 42.4 & 43.7 & 42.1 & 43.5 & 45.3 & 43.6 \\
5. BrunatneBio Złoto & 45.6 & 43.5 & 43.7 & 43.1 & 44.3 & 46.4 & 44.6 \\
\hline Mean & 44.2 & 42.6 & 43.6 & 42.2 & 43.6 & 44.8 & 43.5 \\
\hline
\end{tabular}

$\mathrm{LSD}_{0.05}$ for: cultivars -0.63 ; objects -0.31 ; years -0.63 ; interaction: objects $\mathrm{x}$ years -0.54 ; cultivars $\mathrm{x}$ years -1.1 ; cultivars x objects -0.46 ; cultivars $\mathrm{x}$ objects $\mathrm{x}$ years -0.8

Table 3. Mean daily intake of iron and manganese with diet

\begin{tabular}{|c|c|c|c|c|c|}
\hline \multirow[b]{2}{*}{ Component } & \multirow{2}{*}{$\begin{array}{c}\text { Range in dry } \\
\text { matter } \\
\text { mean }\left(\mathrm{mg} \cdot \mathbf{k g}^{-1}\right)\end{array}$} & \multirow{2}{*}{$\operatorname{Mean}\left(\mathbf{m g} \cdot \mathbf{k g}^{-1}\right)$} & \multirow{2}{*}{$\begin{array}{l}\text { Dietary reference } \\
\text { intake/day }^{1}\end{array}$} & \multicolumn{2}{|c|}{ Percent of realization } \\
\hline & & & & Women & Men \\
\hline $\begin{array}{c}\text { Iron }(\mathrm{Fe}) \\
\text { Manganese (Mn) }\end{array}$ & $\begin{array}{c}41.5-46.4 \\
3.5-5.0\end{array}$ & $\begin{array}{c}43.5 \\
4.4\end{array}$ & $\begin{array}{c}8(\mathrm{mg}) \\
1.8-2.3(\mathrm{mg})\end{array}$ & $\begin{array}{l}5.5 \\
1.7\end{array}$ & $\begin{array}{l}5.5 \\
2.2\end{array}$ \\
\hline
\end{tabular}

${ }^{\mathbf{1}}$ By National Academy of Sciences Food and Nutrition Board USA (Jarosz, 2012)

Table 4. Content of manganese in tubers of potatoes depending on the biostimulator used

\begin{tabular}{c|c|c|c|c|c|c|c}
\hline \multirow{2}{*}{ Objects } & \multicolumn{3}{|c|}{ Cultivars } & \multicolumn{3}{c|}{ Years } & \multirow{2}{*}{ Mean } \\
\cline { 2 - 7 } & Honorata & Jelly & Tajfun & $\mathbf{2 0 1 5}$ & $\mathbf{2 0 1 6}$ & $\mathbf{2 0 1 7}$ & \\
\hline 1. Control object & 4.4 & 4.7 & 4.5 & 4.2 & 4.5 & 4.9 & 4.5 \\
2. Kelpak SL & 4.2 & 4.4 & 3.5 & 3.6 & 3.8 & 4.7 & 4.0 \\
3. Tytanit & 4.2 & 4.5 & 4.5 & 4.1 & 4.2 & 4.9 & 4.4 \\
4. GreenOk & 4.1 & 4.5 & 4.4 & 4.0 & 4.2 & 4.7 & 4.3 \\
5. BrunatneBio Złoto & 4.6 & 4.8 & 4.8 & 4.5 & 4.7 & 5.0 & 4.7 \\
\hline Mean & 4.3 & 4.6 & 4.3 & 4.1 & 4.3 & 4.8 & 4.4 \\
\hline
\end{tabular}

$\mathrm{LSD}_{0.05}$ for: cultivars -0.33 ; objects -0.43 ; years -0.33 ; interaction: objects $\mathrm{x}$ years -0.75 ; cultivars $\mathrm{x}$ years -0.58 ; cultivars $\mathrm{x}$ objects -0.64 ; cultivars $\mathrm{x}$ objects $\mathrm{x}$ years -1.11

\section{Conclusions}

The content of iron and manganese in potato tubers was significantly differentiated by the genotype of the variety. The highest concentration of Mn was found in the Jelly variety tubers, and of iron in the Honorata variety tubers. Tubers of plants treated with the BrunatneBio Złoto Cytokiny preparation were characterized by the highest content of iron and manganese. Weather conditions, particularly the high amount of rainfall in 2017 , contributed to the increase of iron and manganese in potato tubers. 


\section{REFERENCES}

[1] Błoniarz, J., Zaręba, S., Rahnama, M. (2005): Iron and manganese in selected herbs and herbal-fruit teas. - RPZHAW 53(2): 179-188 (in Polish).

[2] Czuba, R. (2000): Micronutrients in modern fertilization systems. - Zesz. Probl. Post. Nauk Roln. 471: 161-169 (in Polish).

[3] Dresow, J. F., Krause, T., Haase, N. U., Loges, R., Heß, J., Böhm, H. (2013): Effect of different defoliation systems of ryegrass-clover on yield and selected quality parameters of organic potatoes (Solanum tuberosum L.) for industrial processing at harvest and after storage. - Potato Research 56: 179-204. DOI: 10.1007/s11540-013-9239-8.

[4] Galdón, B. R., Rodriguez, L. H., Mesa, D. R., Leon, H. L., Perez, N. L., Rodriguez, E. M. R., Romero, C. D. (2012): Differentiation of potato cultivars experimentally cultivated based on their chemical composition and by applying linear discriminant analysis. - Food Chemistry 133: 1241-1248.

[5] Gąsior, J. (1996): Effect of nitrogen fertilization and harvesting time on the content of Iron in potato tubers. - Zesz. Probl. Post. Nauk Roln. 434: 243-248 (in Polish).

[6] Griffiths, A. M., Cook Eggett, D. L., Christensen, M. J. (2012): A retail market study of organic and conventional potatoes (Solanum tuberosum): mineral content and nutritional implications. - Int. J. Food Sci. Nutr. 63(4): 393-401.

[7] Grzyś, E. (2012): The Effect of Selected Biologically Active Substances on Maize Cultivated under Stress Conditions. - Monografie CXLV. Wyd. UP, Wrocław (in Polish).

[8] Jarosz, E. (2012): Nutritional Standards for the Population of Poland. - Institute of Food and Nutrition, Warsaw, pp. 106-107 (in Polish).

[9] Jędrzejczak, R. (2004): Iron and manganese in food. - Rocz. Państ. Zakł. Hig. 55: 13020 (in Polish).

[10] Kabata-Pendias, A., Pendias, H. (1993): Biogeochemistry of Trace Elements. - PWN, Warszawa.

[11] Kaniuczak, J., Hajduk, E., Właśniewski, S. (2009): Effect of liming and mineral fertilization on the content of manganese and zinc in potato tubers and green mass of fodder sunflower cultivated on loess soil. - Zesz. Probl. Post. Nauk Rol. 541: 199-206 (in Polish).

[12] Kucharzewski, A., Dębowski, M. (2001): Evaluation of the State of Contamination of Agricultural Produce in the Area of the Lower Silesia Voivodship. - Stacja ChemicznoRolnicza we Wrocławiu, Wrocław, pp. 3-67 (in Polish).

[13] Kucharzewski, A., Nowak, L., Dmowski, Z., Markowska, J. (2002): The content of heavy metals and sulfur in potatoes in Lower Silesia. - Zesz. Probl. Post. Nauk Roln. 489: 491497 (in Polish).

[14] Kunachowicz, H., Nadolna, I., Iwanow, K., Przygoda, B. (2010): The Nutritional Value of Selected Foods and Typical Dishes. - Wyd. Lekarskie PZWL, Warszawa (in Polish).

[15] Law on Food and Nutrition Safety (2009): Dz. U. 2009, 98, poz. 817.

[16] Leszczyński, W., Lisińska, G. (1986): The effect of nitrogen fertilization and the date of potato planting of Atol, Tisa and Reda varieties on changes in the quality of tubers. Biul. Inst. Ziemn. 34: 63-72 (in Polish).

[17] Lipiński, W., Franczak, S., Watros, A. (2006): Influence of granulometric composition, $\mathrm{pH}$ and organic matter of soil on the content of iron and manganese from wheat grain. $-\mathrm{J}$. Elementol. 11(1): 35-42 (in Polish).

[18] Lombardo, S., Pandino, G., Mauromicale, G. (2014): The mineral profile in organically and conventionally grown "early" crop potato tubers. - Sci. Horticult. 167: 169-173.

[19] Lutaladio, N., Castaidi, L. (2009): Potato: The hidden treasure. - J. Food Comp. Anal. 22: 491-493.

[20] Maciejewski, T., Szukała, J., Jarosz, A. (2007): The impact of the Asahi SL biostimulator on the quality characteristics of potato tubers. - J. Res. Appl. Agric. Eng. 52(3): 109-112 (in Polish). 
[21] Mikos-Bielak, M. (1999): Impact in geNeral in the Districts of Stalowa Wola on the Content of Macro and Micronutrients in Potato Tubers. - Mat. Konf. Ziemniak jadalny i dla przetwórstwa spożywczego czynniki agrotechniczne i przechowalnicze warunkujące jakość. IHAR, Radzików, pp. 189-191 (in Polish).

[22] Mikos-Bielak, M., Sawicka, B. (1992): Zmienność zawartości mikroelementów w bulwach poszczególnych odmian ziemniaków. - VII Symp. Mikroelementy w rolnictwie, pp. 136-140.

[23] Ostrowska, A., Gawliński, S., Szczubiałka, Z. (1991): Methodology and Assessment of Soil and Plant Properties Wyd. - Inst. Ochrony Środowiska, Warszawa (in Polish).

[24] Panda, D., Pramanik, K. B., Naya, R. (2012): Use of sea weed extracts as plant growth regulators for sustainable agriculture. - Int. J. Bioresource and Stress Manag. 3(3): 404411.

[25] Papenfus, H. B., Kulkarni, M. G., Strik, W. A., Finnie, J. F., van Staden, J. (2013): Effect of a commercial seaweed extract (Kelppak) and polyamines on nutrient-deprived (N, P and K) okra seedlings. - Sci. Horticult. 151: 142-1146.

[26] Petryk, A., Bedla, D. (2010): Evaluation of Pb, Zn, Cr, Fe content in potato tubers and in soil in the commune of Trzebinia. - Inżynieria Ekologiczna 22: 18-24 (in Polish).

[27] Prośba-Białczyk, U., Mydlarski, M. (2000): The influence of habitat conditions and varietal properties on the content of trace elements in potato tubers. - Biuletyn IHAR 213: 45-53 (in Polish).

[28] Rogóż, A. (2009): The content of trace elements in soils and selected root crops. Cz II. The content of manganese and iron. - Zesz. Probl. Post. Nauk Rol. 541(2): 365-373 (in Polish).

[29] Rogóż, A., Trąbczyńska, K. (2009): The content of trace elements in soils and selected root crops. Vol. I. Copper and zinc content. - Zesz. Probl. Post. Nauk Rol. 541(2): 353363 (in Polish).

[30] Różyło, K., Pałys, E. (2006): Effect of fertilization and soil conditions on the chemical composition of potato tubers and their health condition. - Zesz. Probl. Post. Nauk Rol. 511: 279-286 (in Polish).

[31] Sawicka, B. (1996): They enter the game of manganese and iron in tubers of early potato varieties during the growing season. - Zesz. Probl. Post. Nauk Roln. 434: 225-229 (in Polish).

[32] Sawicka, B., Mikos-Bielak, M. (2008): Modification of Potato Tuber Chemical Composition by Applications of the Asahi SL Biostimulator. - In: Dąbrowski, Z. T. (ed.) Biostimulators in Modern Agriculture. - Solanaceous Crops. Editorial House Wieś Jutra, Warszawa, pp. 61-67.

[33] Spiak, Z. (2000): Micronutrients in agriculture. - Zesz. Probl. Post. Nauk Roln. 471: 2934 (in Polish).

[34] Srek, P., Hejcman, M., Kunzova, E. (2012): Effect of long-term cattle slurry and mineral $\mathrm{N}, \mathrm{P}$ and $\mathrm{K}$ application on concentrations of $\mathrm{N}, \mathrm{P}, \mathrm{K}, \mathrm{Ca}, \mathrm{Mg}, \mathrm{As}, \mathrm{Cd}, \mathrm{Cr}, \mathrm{Cu}, \mathrm{Mn}, \mathrm{Ni}, \mathrm{Pb}$ and Zn in peeled potato tubers and peels. - Plant Soil Environ. 58(4): 167-173.

[35] Subramanian, N. K., White, P. J., Broadley, M. R., Ramsay, G. (2011): The threedimensional distribution of minerals in potato tubers. - Ann. Bot. 107(4): 681-691.

[36] Sykut, S., Ruszkowska, M., Wojcieska, U., Kusio, M. (1998): The content of manganese in plants as an indicator of the degree of soil acidification. - Zesz. Probl. Post. Nauk Roln. 456: 233-236.

[37] Whittaker, A., Marotti, I., Dinelli, G., Calamai, L., Romagnoli, S., Manzelli, M., Palchetti, E., Vecchio, V., Benedettelli, S. (2010): The influence of tuber mineral element composition as a function of geographical location on acrylamide formation in different Italian potato genotype. - Journal of the Science of Food and Agriculture 90: 1968-1976. DOI $10.1002 /$ jsfa.4026. 
[38] Wierzbicka, A. (2012): Mineral content of potato tubers grown in the organic system their nutritional value and interaction. - J. of Research and Applications in Agricultural Engineering 57(4): 188-192 (in Polish).

[39] Wierzbicka, A., Trawczyński, C. (2011): Influence of irrigation and soil microorganisms on macro and micronutrient content in organic potato tubers. - Frag. Agron. 28(4): 139148.

[40] Wierzbowska, J., Cwalina-Ambroziak, B., Głosek, M., Sienkiewicz, S. (2015): Effect of biostimulators on yield and selected chemical properties of potato tubers. - J. Elem. 20(3): 757-768.

[41] Wierzbowska, J., Cwalina-Ambroziak, B., Bowszyc, T., Głosek-Sobieraj, M., Mackiweicz-Walec, E. (2015): Content of microelements in tubers of potato treated with biostimulators. - Pol. J. Natur. Sc. 30(3): 225-234.

[42] Zarzecka, K.(2004): The content of iron and manganese in potato tubers depending on the weed control methods. - Acta Sci. Pol. Agric. 3(1): 165-173 (in Polish).

[43] Żechałko-Czajkowska, A. (1992): Micronutrients in human food. - VII Symp. Mikroelementy w rolnictwie, pp. 20-25 (in Polish). 